\title{
Past, present and future of the gas market in the North Sea region
}

\author{
Ms A.C. Quinn
}

Managing Director, BP Amoco Gas Marketing Ltd.

While gas markets served by town gas and some reserves of natural gas were well-established in Europe by the mid-nineteenth century, they were largely concentrated in urban areas with supplies insufficient to justify the national and international transport networks, that underpin the Europe-wide gas market, that we see today.

All this was to change with the discovery of significant quantities of natural gas within and adjacent to Europe after the second world war and in particular the birth of a North Sea natural gas industry commencing with Groningen in 1959 and later followed by the British, Norwegian and other gas sectors of the North Sea.

These discoveries heralded the transformation from localized town gas networks to major natural gas systems and with the spread of first national and then international transportation networks within Europe, significant markets for North Sea gas emerged and grew rapidly.

And yet an early, defining feature of these markets was a perception of natural gas as a scarce, relatively high cost premium resource which, would need to be supplemented by the import of less secure and higher cost imports outside of the North Sea region. This perception set the framework for the evolution of the 'managed' approach to markets in gas, that Europe has seen throughout the last 40 years; with state participation in or influence upon the gas chain and in particular via major gas import/ transportation mo- nopolies as well as municipal participation in monopoly utility provision at the distribution level. It has also meant that North Sea natural gas was largely sold only into high value end-use markets in many European countries and not in the generation of base load electricity.

It was not until the 1990's, that a number of factors began to bring new thinking and change to this managed approach to European gas markets. New political agendas, ever greater international competitiveness, significant growth in gas reserves, and rising environmental concerns are among a number of elements that are today driving fundamental change in not just gas, but the broader energy markets of $\mathrm{Eu}$ rope and beyond.

This paper explores that process - from the managed markets stimulated and served so reliably by North Sea gas over 40 years to the changes that have occurred in recent years. It examines the current developments as member states enact legislation to implement the energy Directives nationally and adopt new structures for the effective regulation of their markets in a competitive era. It looks at the new players, who have emerged and the new markets for North Sea gas, in particular in power generation.

And it assesses the future market prospects for North Sea gas in European markets and the growing environmental agenda before concluding with a positive vision of the prospects for natural gas and natural gas markets in and around the North Sea region. 